\title{
Isolation and Characterization of a Novel Alkalitolerant Thermophile, Anaerobranca horikoshii gen. nov., sp. nov.
}

\author{
MARCELLA ENGLE, ${ }^{1}$ YOUHONG LI, ${ }^{1}$ CARL WOESE, ${ }^{2}$ AND JUERGEN WIEGEL ${ }^{1 *}$ \\ Department of Microbiology and Center for Biological Resource Recovery, University of Georgia, Athens, Georgia \\ $30602,{ }^{1}$ and Department of Microbiology, University of Illinois at Urbana-Champaign, Urbana, Illinois 61801 ${ }^{2}$
}

\begin{abstract}
Nine moderately alkalitolerant thermophilic bacteria with similar properties were isolated from water and soil samples obtained from Yellowstone National Park. These Gram-type-positive, rod-shaped bacteria produce cells with primary branches. The cells are peritrichous and exhibit only slight tumbling motility. At $60^{\circ} \mathrm{C}$ the $\mathrm{pH}$ range for growth is 6.9 to 10.3 , and the optimum $\mathrm{pH}$ is 8.5 . At $\mathrm{pH} 8.5$ the temperature range for growth is 34 to $66^{\circ} \mathrm{C}$, with an optimum temperature of $57^{\circ} \mathrm{C}$. The strains are mainly proteolytic. The fermentation products from yeast extract are acetate, $\mathrm{CO}_{2}$, and $\mathrm{H}_{2}$. Fumarate added to minimal medium containing yeast extract is stoichiometrically converted to succinate, indicating that it is used as an alternative electron acceptor. The DNA G+C content is 33 to $34 \mathrm{~mol} \%$. On the basis of its unique properties, such as branch formation, growth at alkaline $\mathrm{pH}$ values at elevated temperatures, and the relative distance of its 16S rRNA sequence from those of other known bacteria, we propose that strain JW/YL-138 ${ }^{\mathrm{T}}(\mathrm{T}=$ type strain) and eight similar strains represent a new genus and species, Anaerobranca horikoshii. Strain JW/YL-138 is designated the type strain of the type species, $A$. horikoshii, which was named in honor of Koki Horikoshi, a pioneer in the field of alkaliphilic bacteria.
\end{abstract}

There has been increasing interest in alkaliphilic bacteria in recent years. The reasons for this include potential industrial applications that require enzymes that are stable at a high $\mathrm{pH}$ values ( $\mathrm{pH} 9.5$ and above) and at temperatures above $50^{\circ} \mathrm{C}(10$, $11,20,30)$. These applications include the use of proteases and xylanases for a nonchlorine bleaching process in the pulp and paper industry. Alkaliphilic bacteria have been isolated from a variety of environments. Most of these isolates, including $\mathrm{Ba}$ cillus alcalophilus (35), belong to the genus Bacillus, and the optimum $\mathrm{pH}$ values of these organisms are between 10 and 11.5. Thus, most of the current information concerning alkaliphiles and $\mathrm{pH}$-stable industrial enzymes has been obtained through studies of these aerobic organisms $(11,14,15)$. Among the anaerobes, many of the alkalitolerant organisms that have been isolated are Archaea (20). These include methanogens such as Methanobacterium alcaliphilum (42), Methanobacterium arbophilicum (43), and Methanococcus vannielii (33), which have optimum $\mathrm{pH}$ values ranging from 7.0 to 9.0 , and halophilic methanogens such as Methanohalophilus zhilinae, which has the highest optimum $\mathrm{pH}$ reported for a member of the Archaea (pH 9.2) (23). Very little is known about the anaerobic alkalitolerant (eu)bacteria, which include one unnamed anaerobe (31) and four unnamed halophilic mesophiles that grow at $\mathrm{pH}$ values between 6.5 and 10.0 (20). One facultative anaerobe, Amphibacillus xylanus, which grows at $\mathrm{pH}$ values between 8.0 and 10.0 (25), has also been described.

Only a few of the known alkaliphiles are also (moderate) thermophiles. The highest recorded growth temperature for an aerobic alkaliphilic Bacillus strain is $57^{\circ} \mathrm{C}(11)$. Among the Archaea, Methanobacterium thermoalcaliphilum has an optimum temperature of 58 to $62^{\circ} \mathrm{C}$ and grows optimally at $\mathrm{pH}$ values ranging from 7.5 to 8.5 (4). Recently, we described the isolation of two alkaliphilic, thermophilic, obligately anaerobic (eu)bacteria, Clostridium paradoxum and Clostridium thermoalcaliphilum, both of which grow optimally at $\mathrm{pH}$ values around 9.0 to 9.5 at 55 and $50^{\circ} \mathrm{C}(5 \mathrm{a})$. Both of these species were

* Corresponding author. Phone: (706) 542-2651. Fax: (706) 5422674. Electronic mail address: jwiegel@uga.cc.uga.edu. isolated from sewage sludge $(18,19)$. In this paper, we describe an anaerobic (eu)bacterial alkalitolerant thermophile, Anaerobranca horikoshii gen. nov., sp. nov., which was isolated from a natural thermobiotic environment, three hot springs in Yellowstone National Park.

\section{MATERIALS AND METHODS}

Sample collection. In May 1990, water and soil samples were taken from different unnamed pools in Yellowstone National Park in the area behind the Old Faithful Hotel and the Ranger Station (Table 1). The samples were collected by completely filling $100-\mathrm{ml}$ sterile bottles and then were brought back at ambient temperature to our laboratory in Athens, Ga.

Isolation and culture conditions. The initial enrichment and isolation were carried out at $60^{\circ} \mathrm{C}$ by using medium $\mathrm{M}-5$, which contained $3.7 \mathrm{mM} \mathrm{KH}_{2} \mathrm{PO}_{4}$ $11.6 \mathrm{mM} \mathrm{Na}_{2} \mathrm{HPO}_{4} \cdot 7 \mathrm{H}_{2} \mathrm{O}, 13.4 \mathrm{mM} \mathrm{KCl}, 3.8 \mathrm{mM}(\mathrm{NH})_{2} \mathrm{SO}_{4}, 9.3 \mathrm{mM} \mathrm{NH}_{4} \mathrm{Cl}$ $0.2 \mathrm{mM} \mathrm{MgCl} \cdot 6 \mathrm{H}_{2} \mathrm{O}, 0.3 \mathrm{mM} \mathrm{CaCl} \cdot \mathrm{H}_{2} \mathrm{O}, 0.3 \%$ (wt/vol) yeast extract, $0.1 \%$ (wt/vol) skim milk, $5.0 \mathrm{ml}$ of a trace element solution (9) per liter, $0.5 \mathrm{ml}$ of a vitamin solution (9) per liter, and $10 \mathrm{ml}$ of a reducing solution $\left(1.25 \mathrm{~g}\right.$ of $\mathrm{Na}_{2} \mathrm{~S}$ per $100 \mathrm{ml}$ and $1.25 \mathrm{~g}$ of cysteic acid per $100 \mathrm{ml}$ ) per liter. Solid media contained $2.2 \%$ (wt/vol) agar (Difco Laboratories, Detroit, Mich.). The $\mathrm{pH}$ was adjusted to 9.0 .

The samples were inoculated into medium M-5 and incubated for 3 to 7 days. The cultures were then serially diluted and used to inoculate agar roll tubes containing medium M-7 solidified with $2 \%$ agar and having $\mathrm{O}_{2}$-free nitrogen as the headspace gas. Medium M-7 contained $0.7 \mathrm{mM} \mathrm{KH} \mathrm{PO}_{4}, 9.3 \mathrm{mM}$ $\mathrm{Na}_{2} \mathrm{HPO}_{4} \cdot 7 \mathrm{H}_{2} \mathrm{O}, 1.3 \mathrm{mM} \mathrm{KCl}, 8.5 \mathrm{mM} \mathrm{NaCl}, 0.2 \mathrm{mM} \mathrm{MgCl}{ }_{2} \cdot 6 \mathrm{H}_{2} \mathrm{O}, 47.2 \mathrm{mM}$ $\mathrm{Na}_{2} \mathrm{CO}_{3}, 0.5 \%$ (wt/vol) yeast extract, $0.3 \%$ (wt/vol) peptone, $0.3 \%$ (wt/vol) tryptone, and vitamins, trace elements, and reducing agent as in medium $\mathrm{M}-5$. The roll tubes were incubated at $60^{\circ} \mathrm{C}$ for 3 to 7 days until colonies appeared. Colonies were picked, transferred to liquid medium, and used to inoculate additional serial dilutions for additional agar roll tubes. Several rounds of isolating single colonies were carried out to ensure the purity of the strains.

Light and electron microscopy. Light microscopy was done with a model PM-10AD phase-contrast microscope (Olympus Optical Co., Ltd., Tokyo, Japan). Transmission electron microscopy was performed with a model JEM-100 CXII electron microscope (JEOL, Tokyo, Japan). The methods of Valentine et al. (34) and Beuscher et al. (2) were used for negative staining. Samples for ultrathin sectioning were prepared by using uranyl acetate and lead citrate for poststaining as described previously $(8,13,32)$.

pH and temperature ranges for growth. The $\mathrm{pH}$ and temperature ranges for growth were determined by using medium M-7 containing $0.5 \%$ (wt/vol) yeast extract as the carbon source. Peptone and tryptone were omitted for the temperature studies. The $\mathrm{pH}$ values used ranged from 6.0 to 11.0 and were measured at $60^{\circ} \mathrm{C}$ with a model $825-\mathrm{MP}$ pH meter (Fisher Scientific, Pittsburgh, Pa.) calibrated at $60^{\circ} \mathrm{C}$ and equipped with a combination $\mathrm{pH}$ electrode (Sensor, Staton, Calif.) and a Fisher Scientific temperature probe. The liquid cultures were inoculated $(2 \%)$ with cells grown at $\mathrm{pH} 8.5$ and were incubated at $60^{\circ} \mathrm{C}$. The 
TABLE 1. Comparison of $A$. horikoshii strains ${ }^{a}$

\begin{tabular}{|c|c|c|c|c|c|c|c|c|c|}
\hline Characteristic & $\begin{array}{c}\text { Strain JW/ } \\
\text { YL-137 }\end{array}$ & $\begin{array}{l}\text { Strain JW/ } \\
\text { YL-138 }\end{array}$ & $\begin{array}{c}\text { Strain JW/ } \\
\text { YL-141 }\end{array}$ & $\begin{array}{c}\text { Strain JW/ } \\
\text { YL-197 }\end{array}$ & $\begin{array}{c}\text { Strain JW/ } \\
\text { YL-254 }\end{array}$ & $\begin{array}{c}\text { Strain JW/ } \\
\text { YL-267 }\end{array}$ & $\begin{array}{c}\text { Strain JW/ } \\
\text { YL-268 }\end{array}$ & $\begin{array}{l}\text { Strain JW/ } \\
\text { YL-269 }\end{array}$ & $\begin{array}{l}\text { Strain JW/ } \\
\text { YL-278 }\end{array}$ \\
\hline $\mathrm{pH}$ of pool ${ }^{b}$ & 6.7 & 6.7 & 6.7 & 6.7 & 6.7 & 5.8 & 5.8 & 5.8 & 8.7 \\
\hline Temp of pool $\left({ }^{\circ} \mathrm{C}\right)^{b}$ & 92 & 92 & 92 & 92 & 92 & 50 & 50 & 50 & 70 \\
\hline Cell width $(\mu \mathrm{m})$ & $0.6-0.7$ & $0.5-0.6$ & $0.4-0.6$ & $0.5-0.6$ & $0.4-0.5$ & $0.5-0.6$ & $0.4-0.6$ & $0.5-0.6$ & $0.5-0.6$ \\
\hline Cell length $(\mu \mathrm{m})$ & $3-10$ & $11-20$ & $13-35$ & $6-20$ & $6-13$ & $4-17$ & $7-15$ & $7-15$ & $3-33$ \\
\hline Minimum $\mathrm{pH}$ for growth & $>6.7,<7.0$ & $>6.7,<7.0$ & $>6.7,<7.0$ & $>6.5,<6.7$ & $>7.0,<7.3$ & $>6.7,<7.0$ & $>6.7,<7.0$ & $>6.7,<7.0$ & $>7.0,<7.3$ \\
\hline Maximum $\mathrm{pH}$ for growth & $>8.5,<9.6$ & $>9.8,<10.3$ & $>9.4,<9.6$ & $>9.8,<10.3$ & $>9.6,<9.8$ & $>9.6,<9.8$ & $>9.6,<9.8$ & $>9.6,<9.8$ & $>9.8,<10.3$ \\
\hline Optimum $\mathrm{pH}$ for growth & 8.5 & 8.5 & 8.5 & 8.8 & 8.8 & 8.5 & 8.7 & 8.5 & 8.7 \\
\hline$m$ temp for $g$ & $>37,<40$ & $>34,<37$ & $>34,<37$ & $>34,<37$ & $>37,<40$ & $>40,<43$ & $>34,<37$ & $>34,<37$ & $>30,<34$ \\
\hline Maximum tem & $>64,<66$ & $>60,<64$ & $>64,<66$ & $>60,<64$ & $>64,<66$ & $>60,<64$ & $>60,<64$ & $>64,<66$ & $>64,<66$ \\
\hline $\mathrm{G}+\mathrm{C}$ content $(\mathrm{mol} \%)$ & 33 & 34 & 33 & 33 & 33 & 33 & 33 & 33 & 33 \\
\hline \multicolumn{10}{|l|}{ Enzymes produced } \\
\hline$\alpha$-Glucosidase & $+(+)^{c}$ & $-(t)$ & $+(+)$ & $+(+)$ & $-(-)$ & $-(-)$ & $-(-)$ & $-(-)$ & $-(-)$ \\
\hline cosidase & $+(+)$ & $-(+)$ & $+(+)$ & $+(+)$ & $+(+)$ & $+(+)$ & $+(+)$ & $+(+)$ & $-(+)$ \\
\hline$\alpha$-Galactosidase & $-(-)$ & $-(+)$ & $-(-)$ & $-(-)$ & $-(+)$ & $-(-)$ & $+1-(+)$ & $+(+)$ & $-(-)$ \\
\hline Indo & $+(+)$ & $+(+)$ & $+(+)$ & $+(+)$ & $+(+)$ & $+1-(+)$ & $+(-)$ & $-(-)$ & $+(-)$ \\
\hline peptidase & $-(-)$ & $-(-)$ & $+(-)$ & $+(-)$ & $-(-)$ & $+(+)$ & $+(-)$ & $-(-)$ & $+(-)$ \\
\hline Pyroglutamic acid acrylamidase & $+(-)$ & $+(-)$ & $-(-)$ & $+(-)$ & $+(-)$ & $-(-)$ & $+(-)$ & $-(-)$ & $+(-)$ \\
\hline Tyrosine aminopeptidase & $-(-)$ & $-(-)$ & $+1-(-)$ & $+(-)$ & $-(-)$ & $+(+)$ & $+(+)$ & $+(+)$ & $+(-)$ \\
\hline Histidine aminopeptidase & $+(+1-)$ & $+(+)$ & $+(+)^{\prime}$ & $+(+)$ & $+(+)$ & $+(+)$ & $+(+)$ & $+(+)$ & $+(-)$ \\
\hline ptidase & $+(-)^{\prime}$ & $+(-)$ & $+(+)$ & $+(+/-)$ & $+(-)$ & $+(+)$ & $+(-)$ & $+(+)$ & $+(-)$ \\
\hline Glycine aminopeptidase & $+(-)$ & $+(+1-)$ & $+(+)$ & $+(+1-)$ & $+(+1-)$ & $+(+)$ & $+(-)$ & $+(+)$ & $+(-)$ \\
\hline Utilization of fumarate & 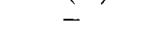 & + & + & + & + & + & + & + & + \\
\hline
\end{tabular}

${ }^{a}$ All strains were positive for the following characteristics: indole production, arginine utilization, and arginine aminopeptidase and alanine aminopeptidase activities. All strains were negative for the following characteristics: $N$-acetyl- $\beta$-glucosaminidase, $\alpha$-arabinosidase, $\alpha$-fucosidase, $\beta$-galactosidase, and proline aminopeptidase activities and catalase production.

${ }^{b}$ Pool from which the strain was isolated.

${ }^{c}$ Results obtained under anaerobic conditions (results obtained under aerobic conditions). + , positive; - , negative; $+/-$, weakly positive.

pH was kept constant ( $\pm 0.1 \mathrm{pH}$ unit) by periodically adding $1 \mathrm{~N} \mathrm{NaOH}$. A temperature gradient incubator (Scientific Industries, Inc., Bohemia, N.Y.) set with a gradient ranging from 30 to $70.5^{\circ} \mathrm{C}$ was used to determine the temperature range for growth. The cultures were inoculated $(2 \%$, vol/vol) with celis grown at $60^{\circ} \mathrm{C}$ and were incubated at $\mathrm{pH} 8.5$. The optimum $\mathrm{pH}$ for JW/YL-138 ${ }^{\mathrm{T}}$ (T $=$ type strain) was corroborated by measuring growth in a $100-\mathrm{ml} \mathrm{pH}$ - and temperaturecontrolled fermentor (Glass Shop, University of Georgia).

Substrate utilization. Modified medium M-5 was used to determine the substrate spectrum. This medium contained $3.7 \mathrm{mM} \mathrm{KH}_{2} \mathrm{PO}_{4}, 21.8 \mathrm{mM} \mathrm{Na}_{2} \mathrm{HPO}_{4}$, $6.6 \mathrm{mM} \mathrm{KCl}, 0.5 \%$ (wt/vol) yeast extract, $5.0 \mathrm{ml}$ of the trace element solution per liter, $0.5 \mathrm{ml}$ of the vitamin solution per liter, $10 \mathrm{ml}$ of the reducing solution per liter, and 0.5 to $1.0 \%$ (wt/vol) substrate. The cultures containing added substrate were inoculated $(2 \%$ ) with 12 -h cultures grown in medium M-5 that did not contain added substrate. They were incubated at $\mathrm{pH} 8.5$ and $60^{\circ} \mathrm{C}$ for approximately $48 \mathrm{~h}$, during which the optical densities and changes in $\mathrm{pH}$ were monitored. Because of low culture densities (optical density at $600 \mathrm{~nm},<0.3$ ), cultures in which increases in optical density values of more than $0.05 \mathrm{U}$ were accompanied by decreases in the $\mathrm{pH}$, compared with control cultures containing no substrate supplements, were considered positive for substrate utilization.

Fermentation products. The fermentation products were analyzed by using modified medium M-5 (see above) containing $0.5 \%$ (wt/vol) yeast extract with and without $6 \mathrm{mM}$ fumarate as substrate. The cultures were incubated at $\mathrm{pH} 8.5$ and $60^{\circ} \mathrm{C}$. Volatile and nonvolatile fatty acids were analyzed by gas chromatography by using a model $5880 \mathrm{~A}$ gas chromatograph (Hewlett-Packard, Palo Alto, Calif.) equipped with a Chromosorb WAW 10\% sp-100 glass column (Supelco Inc., Bellefonte, $\mathrm{Pa}$.) and a flame ionization detector (39). Production of $\mathrm{H}_{2}$ and $\mathrm{CO}_{2}$ was analyzed by gas chromatography by using a chromatograph (Varian, Walnut Creek, Calif.) equipped with a Porapak Q 80/100-mesh column (Supelco) and a thermal conductivity detector (19). Glucose and acetate contents were determined by performing enzymatic assays (catalog no. 139106 and 148261, respectively; Boehringer GmbH, Mannheim, Germany).

DNA isolation and determination of $\mathbf{G}+\mathbf{C}$ content. DNA was isolated from cells in the exponential growth phase by the method of Ausubel et al. (1) by using $\mathrm{CsCl}$ gradient ultracentrifugation. The DNA was enzymatically digested, and the guanine-plus-cytosine $(\mathrm{G}+\mathrm{C})$ content was determined by high-performance liquid chromatography separation of the nucleosides as described by Whitman et al. (38) and Mesbah et al. (24).

16 S rRNA sequence analysis. 16S rRNAs were isolated from strains JW/YL$138^{\mathrm{T}}$ and JW/YL-268 by a previously described procedure $(22,41)$. The dideoxynucleotide chain termination method $(3,28)$ adapted for direct rRNA sequencing with reverse transcriptase (16) was used. Synthesized strands were labeled by including $\left[\alpha-{ }^{35}\right.$ S $]$-thio-dATP (3). A standard set of primers (usually eight) specific for (eu)bacterial $16 \mathrm{~S}$ rRNAs $(3,16,37)$ was used routinely. All of the sequences were $>90 \%$ complete. The sequences were aligned by using sequence editor ae2 (C. R. Woese, University of Illinois) with the sequences of a representative collection of (eu)bacterial 16S rRNAs. Corrected pairwise distances (expressed as estimated number of changes per 100 nucleotides) were computed from the percentages of similarity by using the Jukes-Cantor correction (12) as modified by Olsen et al. (27) to accommodate the actual nucleotide ratios. Dendrograms were constructed from evolutionary distance matrices by using the algorithm of De Soete (6), and the reduced dendrogram shown in Fig. 1 was produced. The rRNA sequence of $A$. horikoshii (strains JW/YL-138 ${ }^{\mathrm{T}}$ and JW/YL-268) was located phylogenetically by using the publically available maximum-likelihood analysis method (26) offered by the Ribosomal Database

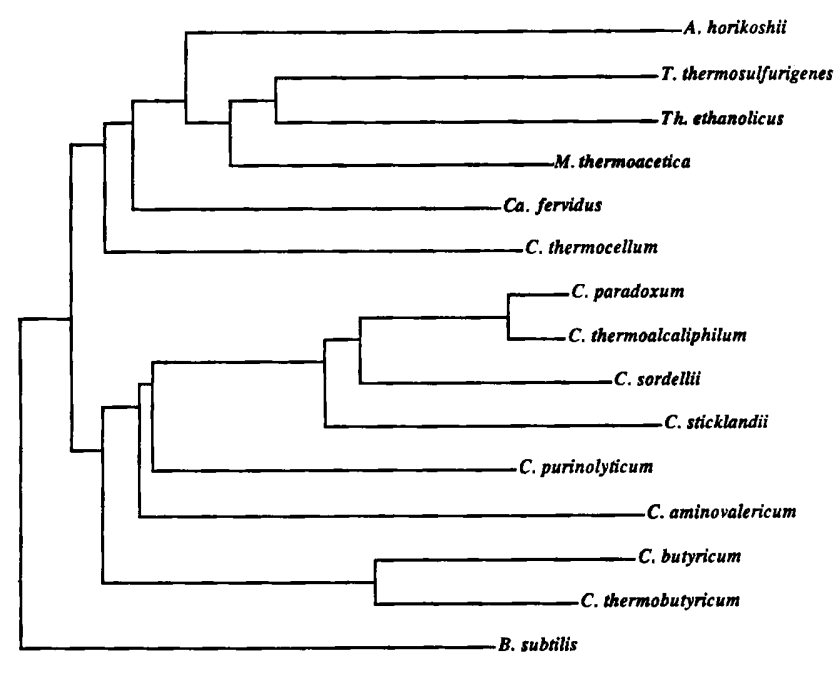

FIG. 1. Phylogenetic tree for $A$. horikoshii and related organisms based on 16S rRNA sequences. Bar $=5$ inferred changes per 100 nucleotides. Bacillus subtilis was used as an arbitrary outgroup. Abbreviations: $C$., Clostridium; Th., Thermoanaerobacter; B., Bacillus; T., Thermoanaerobacterium; Mo., Moorella; $A$., Anaerobranca; $\mathrm{Ca}$., Caloramator. 
TABLE 2. Evolutionary distances between $A$. horikoshii and selected members of the clostridial subphylum

\begin{tabular}{|c|c|c|c|c|c|c|c|c|c|c|c|c|c|c|}
\hline \multirow[b]{2}{*}{ Organism } & \multicolumn{14}{|c|}{ Evolutionary distance (\%) to: } \\
\hline & 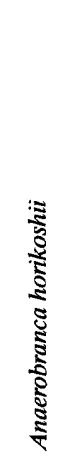 & 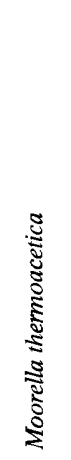 & 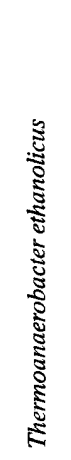 & 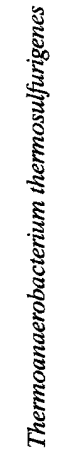 & 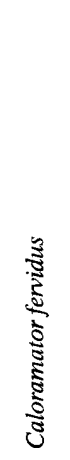 & 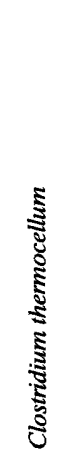 & 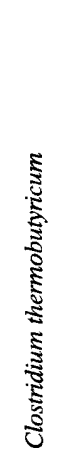 & 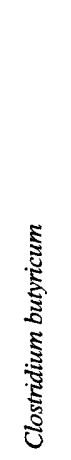 & 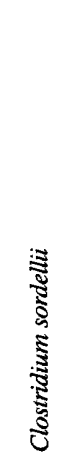 & 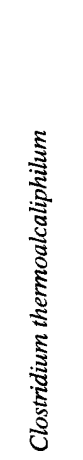 & 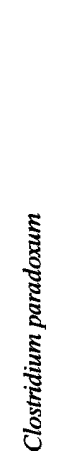 & 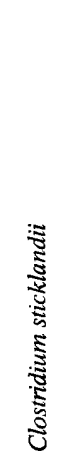 & 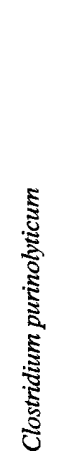 & 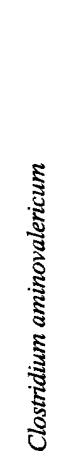 \\
\hline Moorella thermoacetica & 14.0 & & & & & & & & & & & & & \\
\hline Thermoanaerobacter ethanolicus & 17.3 & 12.5 & & & & & & & & & & & & \\
\hline Thermoanaerobacterium thermosulfurigenes & 16.5 & 13.3 & 13.1 & & & & & & & & & & & \\
\hline Caloramator fervidus & 17.2 & 13.3 & 14.3 & 14.9 & & & & & & & & & & \\
\hline Clostridium thermocellum & 15.8 & 15.3 & 17.5 & 16.3 & 14.1 & & & & & & & & & \\
\hline Clostridium thermobutyricum & 17.9 & 18.0 & 19.3 & 17.8 & 14.4 & 16.4 & & & & & & & & \\
\hline Clostridium butyricum & 19.3 & 19.9 & 21.2 & 20.1 & 15.7 & 17.5 & 7.9 & & & & & & & \\
\hline Clostridium sordellii & 20.6 & 17.4 & 19.6 & 20.5 & 18.1 & 17.3 & 16.7 & 17.0 & & & & & & \\
\hline Clostridium thermoalcaliphilum & 19.2 & 16.1 & 17.2 & 17.6 & 16.2 & 16.7 & 17.0 & 17.7 & 7.7 & & & & & \\
\hline Clostridium paradoxum & 19.4 & 15.5 & 16.9 & 17.3 & 15.7 & 16.5 & 16.9 & 17.7 & 8.0 & 2.0 & & & & \\
\hline Clostridium sticklandii & 21.6 & 18.2 & 19.1 & 19.7 & 17.9 & 16.8 & 17.9 & 18.2 & 10.2 & 9.8 & 10.5 & & & \\
\hline Clostridium purinolyticum & 16.8 & 16.2 & 18.6 & 18.1 & 15.3 & 14.9 & 15.0 & 15.7 & 13.1 & 13.0 & 13.4 & 16.0 & & \\
\hline Clostridium aminovalericum & 20.7 & 18.7 & 20.2 & 20.9 & 16.5 & 15.9 & 17.8 & 17.0 & 14.7 & 16.6 & 17.3 & 17.3 & 15.3 & \\
\hline Bacillus subtilis & 18.8 & 15.8 & 18.9 & 19.4 & 17.0 & 18.2 & 17.5 & 18.5 & 18.3 & 17.1 & 17.5 & 19.6 & 16.4 & 19.4 \\
\hline
\end{tabular}

Project at the University of Illinois (21); this function allows a user-submitted sequence to be introduced into the precalculated Ribosomal Database Project maximum-likelihood tree (data not shown). The taxa used in the latter analysis were chosen (iteratively) to be representative of all species or genera in the phylogenetic vicinity of the $A$. horikoshii lineage. The sequences were chosen from the set of all rRNA sequences available in the major public databases (40).

Nucleotide sequence accession number. The GenBank accession number for the 16S rRNA sequence of type strain JW/YL-138 is U21809.

\section{RESULTS AND DISCUSSION}

Isolation and preliminary characterization. Several strains were isolated from Yellowstone National Park samples as described in Materials and Methods. The enrichment cultures contained yeast extract and skim milk to select for organisms that produce extracellular alkali-stable proteases. Nine different strains were isolated from hot spring samples with $\mathrm{pH}$ values ranging from slightly acidic to alkaline (Table 1 ). The highest measured temperatures of the various pools sampled ranged from 50 to $92^{\circ} \mathrm{C}$ (Table 1); the samples used, however, were collected as composite samples consisting of water and sediment from various parts of each pool. The cellular proteins of seven of the nine strains isolated were extracted and separated by sodium dodecyl sulfate-polyacrylamide gel electrophoresis (data not shown). The similar band patterns on the gel, which differed only slightly, and the small differences in cell morphology and substrate utilization (Table 1) suggested that the nine isolates were different strains of the same species. All of the isolates produced proteases, but none of them were EDTA resistant, indicating that the proteases are probably metalloenzymes (data not shown). Strains JW/YL-138 ${ }^{\mathrm{T}}$ and JW/YL-268 were chosen for further characterization.

Phylogeny. The tree in Fig. 1 is the result of a least-squares analysis (6) based on the evolutionary distance matrix shown in Table 2 (see Materials and Methods). The 16S rRNA se- quences of strains JW/YL-138 ${ }^{\mathrm{T}}$ and JW/YL-268 (A. horikoshii) were also located phylogenetically by using the publically available maximum-likelihood analysis method (26) offered by the Ribosomal Database Project at the University of Illinois (21). Although the distance tree in Fig. 1 and the maximum-likelihood tree did not agree completely, they are very similar in topology, and both permit the following conclusions regarding A. horikoshii: (i) this organism has no known close relatives among the previously described bacteria (and therefore represents a novel genus), and (ii) it belongs to the large subgroup consisting of low-G+C-content Gram-type-positive bacteria. The most closely related organisms are Moorella thermoacetica (basonym, Clostridium thermoaceticum) (relative distance, $14.0 \%$ ), Clostridium thermocellum (relative distance, 15.8\%), Thermoanaerobacterium thermosulfurigenes (relative distance, $16.5 \%$ ), and Clostridium purinolyticum (relative distance, 16.8\%) (Fig. 1 and Table 2). Relative distances of more than 8 to $10 \%$ are regarded as distances that permit placing bacteria (which are related to species in the presently ill-defined genus Clostridium) into separate genera as long as this placement is consistent with physiological data (11a). In the future, only species that cluster around the type species of the genus Clostridium, Clostridium butyricum, and produce butyrate as the major fermentation product will remain members of the genus Clostridium. The relative distance between the 16S rRNA sequences of strains JW/YL-138 ${ }^{\mathrm{T}}$ and JW/YL-268 and the sequences of all of the other bacteria analyzed, especially the clostridial species clustering in the tree around type species $C$. butyricum (5a), justify the creation of a new genus. Therefore, on the basis of the morphological and physiological differences observed (see below) (Table 3) and the 16S rRNA sequence data described above, we consider strains JW/YL-138 ${ }^{\mathrm{T}}$ and JW/YL-268 and similar isolates members of a novel species in 
TABLE 3. Characteristics that differentiate $A$. horikoshii from other phylogenetically related organisms

\begin{tabular}{|c|c|c|c|c|c|}
\hline Characteristic & $\begin{array}{l}\text { Anaerobranca } \\
\text { horikoshii }\end{array}$ & $\begin{array}{c}\text { Moorella } \\
\text { thermoacetica }\end{array}$ & $\begin{array}{l}\text { Clostridium } \\
\text { thermocellum }\end{array}$ & $\begin{array}{l}\text { Thermoanaerobacterium } \\
\text { thermosulfurigenes }\end{array}$ & $\begin{array}{c}\text { Clostridium } \\
\text { purinolyticum }\end{array}$ \\
\hline $\begin{array}{l}\mathrm{G}+\mathrm{C} \text { content } \\
(\mathrm{mol} \%)\end{array}$ & $33-34$ & 54 & $38-39$ & 33 & 29 \\
\hline $\mathrm{pH}$ range & $6.5-10.3$ & $5.4-7.8$ & $6.0-8.0$ & $4.0-7.6$ & $6.5-9.0$ \\
\hline Optimum pH & $8.5-8.8$ & $6.6-6.8$ & $6.8-7.2$ & $5.5-6.5$ & $7.3-7.8$ \\
\hline Optimum temp $\left({ }^{\circ} \mathrm{C}\right)$ & 57 & $55-60$ & $60-64$ & 60 & 36 \\
\hline Maximum temp $\left({ }^{\circ} \mathrm{C}\right)$ & 66 & 65 & 68 & 75 & 42 \\
\hline Spore formation & - & + & + & + & + \\
\hline Branch formation & + & - & - & - & - \\
\hline $\mathrm{S}_{2} \mathrm{O}_{3} \rightarrow \mathrm{S}^{0}$ & - & - & - & + & - \\
\hline Fumarate $\rightarrow$ succinate & + & - & - & - & - \\
\hline Proteolytic & + & - & - & - & - \\
\hline \multicolumn{6}{|l|}{ Utilization of: } \\
\hline Glucose & - & + & $(+)^{a}$ & + & - \\
\hline Cellulose & - & - & + & - & - \\
\hline Xylose & - & + & - & - & - \\
\hline Pyruvate & - & + & + & - & + \\
\hline Pectin & - & - & - & + & - \\
\hline Purine & - & - & - & - & + \\
\hline Glycine & - & - & - & - & + \\
\hline $\mathrm{H}_{2}-\mathrm{CO}_{2}$ & - & + & - & - & - \\
\hline
\end{tabular}

${ }^{a}$ Parentheses indicate that the organism must be adapted for growth.

a novel genus, for which we propose the name Anaerobranca. On the basis of the high level of similarity of the sequences of strains JW/YL-138 ${ }^{\mathrm{T}}$ and JW/YL-268 and the physiological data and protein patterns, all of the isolates which we studied were included in one species, $A$. horikoshii.

Habitat. So far, all $A$. horikoshii strains have been isolated only from hot springs in the Old Faithful Hotel area (behind the Ranger Station) in Yellowstone National Park. Using the enrichment procedures described above or very similar enrichment procedures, we obtained no similar isolates from hot springs in Iceland, New Zealand, Italy, and other parts of the United States (including other hot springs in Yellowstone National Park) or from man-made thermobiotic environments, such as sewage sludge, compost, and manure piles.

Colony and cell morphology. The colonies of JW/YL-138 on agar surfaces are white and circular, and the colonies inside agar are lens shaped. The cells are rod shaped in all growth phases in both liquid cultures and solid cultures. The rods range from 8.0 to $22 \mu \mathrm{m}$ long and from 0.50 to $0.65 \mu \mathrm{m}$ wide (Table 1 and Fig. 2). The average length of the cells is longer in the stationary growth phase than in the exponential growth phase (Fig. 2A to D). The cells exhibit a low frequency (between 1.0 and $10.0 \%$ ) of primary branch formation (Fig. 2 and 3 ). The extent or frequency of branch formation is not noticeably affected by $\mathrm{pH}$, temperature, or nutrient conditions, such as the absence or presence of tryptone, peptone, sugars, or various concentrations of yeast extract. Such branch formation has not been observed in any other obligately anaerobic bacterium.

The cells are peritrichous. Some strains, including the type strain, exhibit tumbling motility when they are grown in the presence of low yeast extract concentrations $(0.01 \%$, wt/vol).

Strain JW/YL-138 ${ }^{\mathrm{T}}$ has not been observed to produce spores when it is grown in liquid medium or on solid medium, including medium containing limiting nutrient concentrations, or in the presence of nonutilized sugars. Spores have not been observed in any other strain of this species.

The cells stain gram positive in both the exponential and stationary growth phases. An ultrathin-section electron micrograph also revealed a Gram-type-positive cell wall (Fig. 3).
This finding is consistent with the results of the 16S rRNA sequencing study which placed the organism in the Gram-typepositive Clostridium-Bacillus subphylum.

Physiological characterization. (i) Growth requirements. Strain JW/YL-138 ${ }^{\mathrm{T}}$ requires anaerobic conditions for growth. Growth does not occur in oxidized medium, as indicated by the pink color of resazurin. Growth does occur, however, when cells are inoculated into anaerobic medium after the cells have been exposed to aerobic conditions for up to $12 \mathrm{~h}$ at 25 and $60^{\circ} \mathrm{C}$, indicating that the cells are not sensitive to oxygen under nongrowth conditions. Yeast extract is required for growth and can be used as the sole carbon source. Peptone and tryptone ( $0.2 \%$ each) can be used as substitutes for yeast extract, but addition of these compounds does not enhance the growth of $\mathrm{JW} / \mathrm{YL}-138^{\mathrm{T}}$ in the presence of $0.2 \%$ yeast extract.

(ii) $\mathrm{pH}$ and temperature ranges for growth. The temperature range for growth of $\mathrm{JW} / \mathrm{YL}-138^{\mathrm{T}}$ at $\mathrm{pH} 8.5$ is from greater than 34 to less than $66^{\circ} \mathrm{C}$, with an optimum temperature of $57^{\circ} \mathrm{C}$ (Fig. 4B). The $\mathrm{pH}$ range for growth at $60^{\circ} \mathrm{C}$ is from greater than 6.7 to less than 10.3 , with an optimum $\mathrm{pH}$ of 8.5 (Fig. 4A). The $\mathrm{pH}$ and temperature ranges for growth of all of the isolates are shown in Table 2.

(iii) Substrate utilization and fermentation products. The species is mainly proteolytic and is able to grow in the presence of $0.5 \%$ (wt/vol) yeast extract as a sole carbon source. Most strains, including JW/YL-138 ${ }^{\mathrm{T}}$, utilize fumarate in the presence of yeast extract (the concentrations tested were $0,0.5$, and $1.0 \%$ [wt/vol]). Strains JW/YL-138 ${ }^{\mathrm{T}}$ and JW/YL-268 cannot utilize glucose, sucrose, fructose, galactose, maltose, pyruvate, cellobiose, lactose, xylose, ribose, rhamnose, raffinose, arabinose, mannitol, xylitol, Casamino Acids, salicin, glycerate, acetate, lactate, formate, methanol, starch, or pectin.

The fermentation products produced by $\mathrm{JW} / \mathrm{YL}-138^{\mathrm{T}}$ from yeast extract are acetate, $\mathrm{CO}_{2}$, and $\mathrm{H}_{2}$. Fumarate $(12 \mathrm{mM})$ is reduced to succinate in a ratio of approximately $1: 1$, indicating that fumarate is used as an alternative electron acceptor for electrons generated during utilization of components in yeast extract (Table 4). In the absence of fumarate, however, growth of $\mathrm{JW} / \mathrm{YL}-138^{\mathrm{T}}$ is inhibited if medium containing $0.5 \%$ yeast 

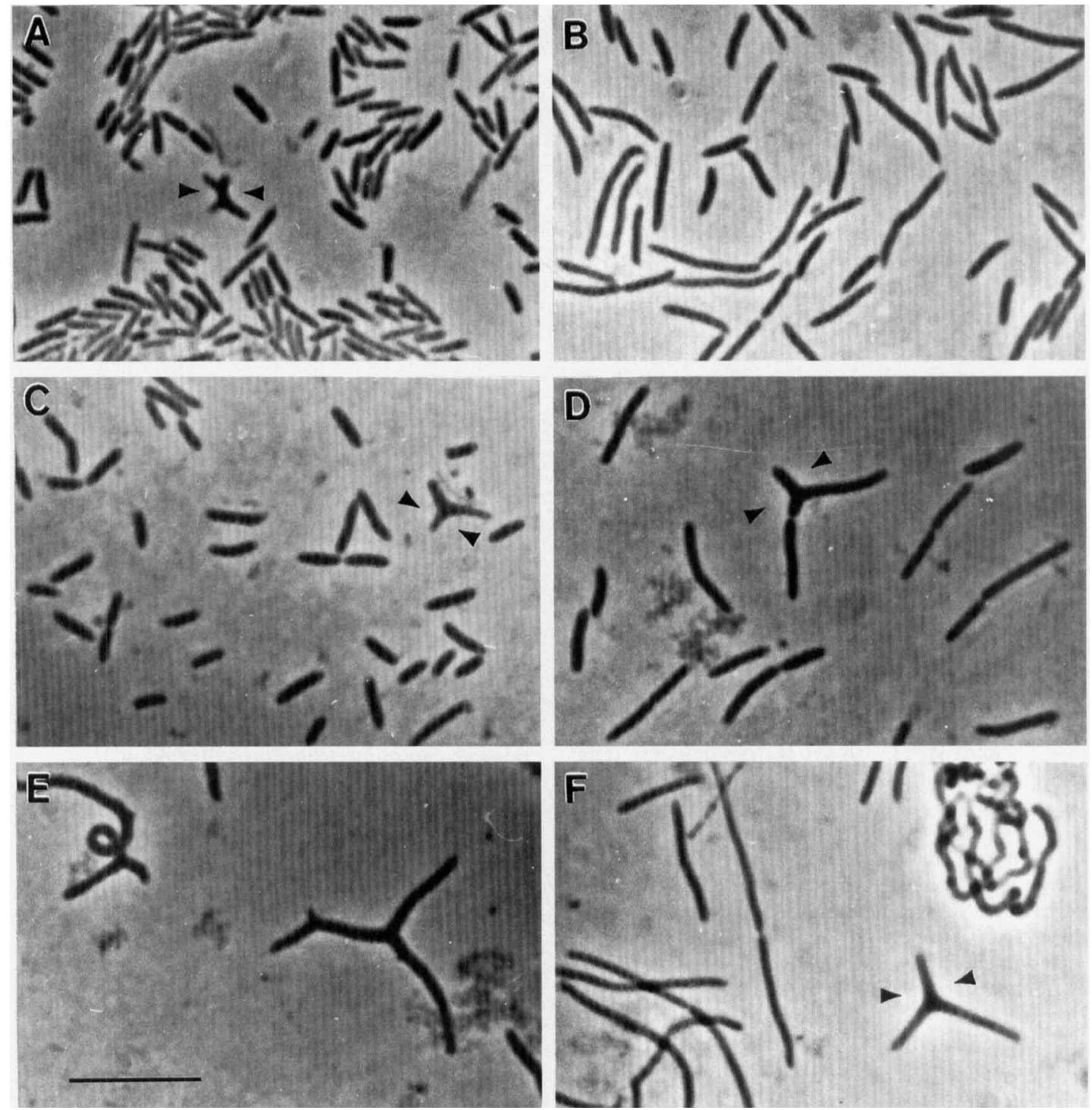

FIG. 2. Light micrographs of $A$. horikoshii. (A and B) Cells of strain JW/YL-138 $8^{\mathrm{T}}$ in the exponential (A) and stationary (B) growth phases. (C and D) Cells of strain JW/YL-268 in the exponential (C) and stationary (D) growth phases. (E and F) Cells of strain JW/YL-197 (E) and JW/YL-278 (F) in the stationary growth phase. The arrowheads indicate branch formations. Bar $=10 \mu \mathrm{m}$. The cultures were incubated at $\mathrm{pH} 8.5$ and $60^{\circ} \mathrm{C}$.

extract is supplemented with succinate at concentrations of more than $3 \mathrm{mM}$.

Biochemical characterization. (i) Dissimilatory sulfate reduction. There is no dissimilatory sulfate reduction activity when JW/YL-138 ${ }^{\mathrm{T}}$ and JW/YL-268 are grown in the presence of sulfate and glucose, acetate, or lactate as electron acceptors.

(ii) API An-Ident tests. API An-Ident tests were carried out under both aerobic and anaerobic conditions, which generated slightly different results (Table 1). In contrast to the aerobic incubation results, when JW/YL-138 ${ }^{\mathrm{T}}$ was tested under anaerobic conditions, the tests for pyroglutamic acid arylamidase and phenylalanine aminopeptidase activities were positive and the tests for $\alpha$-glucosidase, $\beta$-glucosidase, and $\alpha$-galactosidase activities were negative.

(iii) DNA G+C contents. The DNA G+C contents of the nine isolates range from 33 to $34 \mathrm{~mol} \%$ (Table 1).

Maintenance. Although no spores have been observed in cultures of JW/YL- $138^{\mathrm{T}}$ or any of the other eight isolates, the cultures survive for up to 3 months in liquid medium at room temperature. Liquid cultures stored in a 1:1 glycerol-culture mixture at $-70^{\circ} \mathrm{C}$ remain viable for at least 3 years (the longest time tested).

Differentiation of $\boldsymbol{A}$. horikoshii from other phylogenetically related organisms. The new isolates differ in several important respects from the phylogenetically related bacteria identified by the 16S RNA analysis (Table 3 ). The differences include differences in the DNA G+C contents (the $\mathrm{G}+\mathrm{C}$ content of Moorella thermoacetica [basonym, $C$. thermoaceticum] is 54 $\mathrm{mol} \%$ [4], the G+C content of $C$. thermocellum is $38 \mathrm{~mol} \%$ [36], and the $\mathrm{G}+\mathrm{C}$ content of $C$. purinolyticum is $29 \mathrm{~mol} \%$ [9], compared with the values of 33 to $34 \mathrm{~mol} \%$ obtained for the new isolates) and the absence of cellulose or xylan utilization in $A$. horikoshii $(C$. thermocellum [36] and $T$. thermosulfurigenes [17], respectively, are positive for this characteristic). In addition, $A$. horikoshii is not a homoacetogen like Moorella thermoacetica (4) and is not purinolytic like C. purinolyticum (9). 

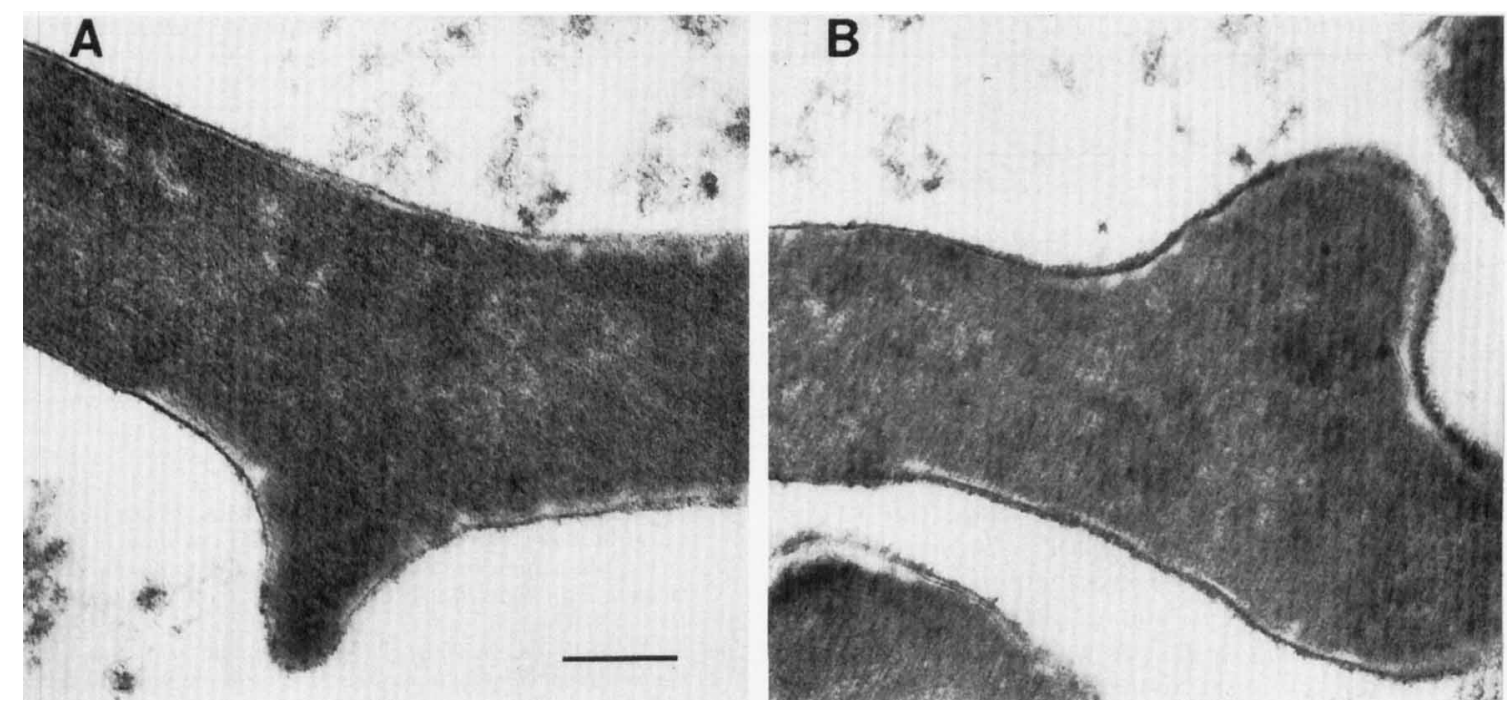

FIG. 3. Ultrathin-section electron micrographs of $A$. horikoshii JW/YL-138 ${ }^{\mathrm{T}}$, showing primary branch formation. There is no septation at the branch junction, and the cell wall appears to be continuous. Bar $=0.2 \mu \mathrm{m}$.

The new isolates do not utilize thiosulfate and do not produce elemental sulfur, a main characteristic of the genus Thermoanaerobacterium (17; unpublished data). The closely related bacteria include spore-forming and non-spore-forming species, demonstrating again that spore formation cannot be regarded as a conservative phylogenetic marker. The strains placed in
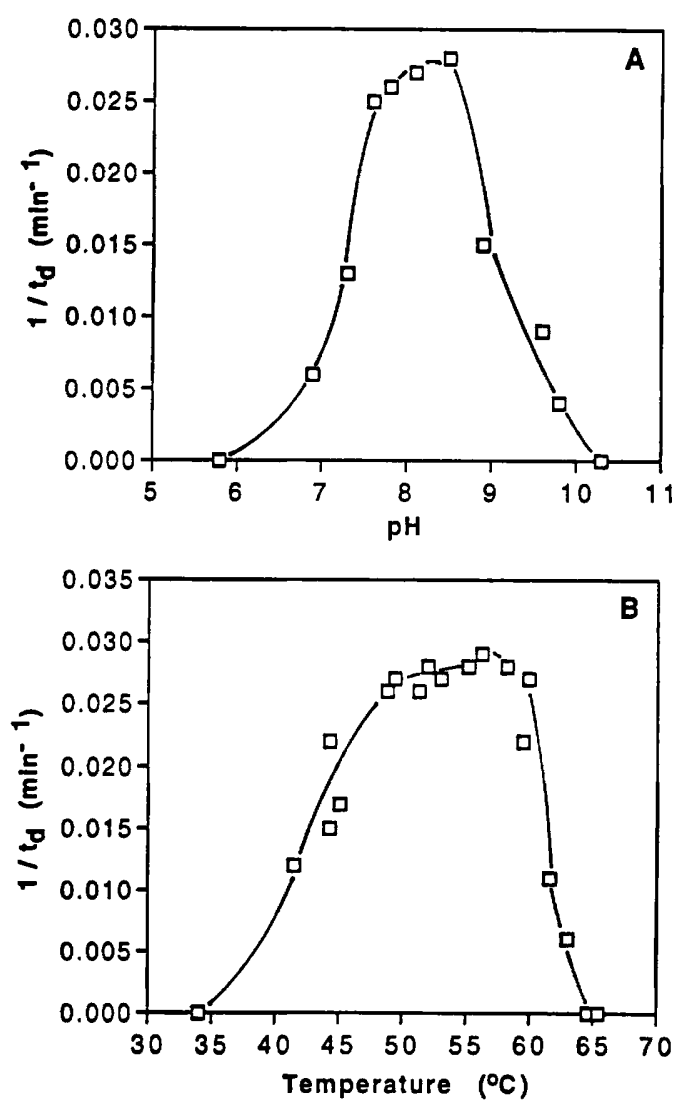

FIG. 4. Effect of $\mathrm{pH}$ at $60^{\circ} \mathrm{C}(\mathrm{A})$ and of temperature at $\mathrm{pH} 8.5$ (B) on the growth of JW/YL-138 ${ }^{\mathrm{T}}$. the new species $A$. horikoshii grow at more alkaline $\mathrm{pH}$ values than the species mentioned above and most other anaerobic bacteria. The other alkaline anaerobic bacteria, such as $C$. paradoxum and $C$. thermoalcaliphilum, are phylogenetically even more distantly related than the organisms mentioned above. On the basis of this analysis, we concluded that the new isolates should be placed in a new genus, for which we propose the name Anaerobranca. On the basis of the high level of similarity of the 16S RNA sequences of two strains, the physiological data, and the cellular protein patterns, all of the isolates are placed in one species, $A$. horikoshii.

Description of the genus Anaerobranca gen. nov. Anaerobranca (An.ae.ro.bran'ca. Gr. pref. an, not; Gr. n. aer, air; M. L. fem. n. branca, claw, paw, the root of the English word branch, an armlike part diverging from a main axis; N. L. $n$. Anaerobranca, referring to the branched cell shape of this obligately anaerobic organism). The cells are Gram reaction and Gram type positive and are generally rod shaped, but some cells form primary branches. Anaerobranca strains are obligately anaerobic, heterotrophic, and proteolytic thermophiles that grow at moderately alkaline $\mathrm{pH}$ values. The $\mathrm{DNA} \mathrm{G}+\mathrm{C}$ content is between 33 and $34 \mathrm{~mol} \%$. A. horikoshii is the type and so far only species in this genus.

Description of Anaerobranca horikoshii sp. nov. Anaerobranca horikoshii (hor.i.kosh'i.i. N. L. gen. n. horikoshii, of Horikoshi, in honor of Koki Horikoshi, a pioneer in the study of the microbiology of alkaliphilic bacteria). The rod-shaped cells, which are 8 to $22 \mu \mathrm{m}$ long and 0.5 to $0.65 \mu \mathrm{m}$ in diameter, form one to three branches at a frequency of 1 to $10 \%$, and these branches can form daughter cells by restriction. The cells are peritrichous and, during growth in low-nutrient medium (e.g., medium containing less than $0.1 \%$ yeast extract), exhibit slight tumbling motility. Spores have not been detected. Chemoorganotrophic and mainly proteolytic. Yeast extract is required for growth and can be used as the sole carbon source. During growth on yeast extract, if fumarate is added, it is reduced stoichiometrically to succinate. All isolates are moderately alkaliphilic thermophiles. The temperature range for growth is 30 to $66^{\circ} \mathrm{C}$, with an optimum temperature of $57^{\circ} \mathrm{C}$, and the $\mathrm{pH}$ range for growth is 6.5 to 10.3 , with an optimum $\mathrm{pH}$ of 8.5 . The DNA base composition is 33 to $34 \mathrm{~mol} \% \mathrm{G}+\mathrm{C}$. 
TABLE 4. Fermentation products of JW/YL- $138^{\mathrm{T}}$ obtained from yeast extract and products obtained from reduction of fumarate

\begin{tabular}{|c|c|c|c|c|c|c|}
\hline \multirow{2}{*}{ Substrate(s) added } & \multirow{2}{*}{$\mathrm{OD}_{600}{ }^{a}$} & \multirow{2}{*}{$\begin{array}{l}\text { Amt of fumarate } \\
\text { used }(\mu \mathrm{mol} / \mathrm{ml})\end{array}$} & \multicolumn{4}{|c|}{ Amt of products $(\mu \mathrm{mol} / \mathrm{ml})$} \\
\hline & & & Acetate & Succinate & $\mathrm{CO}_{2}$ & $\overline{\mathrm{H}_{2}}$ \\
\hline Yeast extract $(0.5 \%)$ & 0.150 & & 4.4 & & 4.1 & 2.2 \\
\hline Fumarate $(12 \mathrm{mM})+$ yeast extract $(0.5 \%)$ & 0.390 & 9.9 & 9.3 & 7.3 & 7.3 & 1.9 \\
\hline
\end{tabular}

${ }^{a} \mathrm{OD}_{600}$, optical density at $600 \mathrm{~nm}$.

16S rRNA analysis data place this organism in the Gram-typepositive Clostridium-Bacillus subphylum, but there are no closely related species (i.e., species whose relative distance is less than $10 \%$ ).

Strain JW/YL-138 (= DSM 9786) is the type strain of $A$. horikoshii and has a $\mathrm{G}+\mathrm{C}$ content of $34 \mathrm{~mol} \%$. Its $\mathrm{pH}$ range for growth is from greater than 6.7 to less than $10.3\left(60^{\circ} \mathrm{C}\right)$. Its temperature range for growth is from greater than 34 to less than $64^{\circ} \mathrm{C}$. The cells are 0.5 to $0.6 \mu \mathrm{m}$ wide and 11 to $20 \mu \mathrm{m}$ long. Fumarate is reduced to succinate in the presence of yeast extract as a growth substrate.

\section{ACKNOWLEDGMENT}

J.W. thanks Rick Hutchinson, Yellowstone National Park, for his valuable help and for providing essential information for the collection of samples from various park areas.

\section{REFERENCES}

1. Ausubel, F. M., R. Brent, R. E. Kingston, D. D. Moore, J. G. Seidman, J. A. Smith, and K. Struhl. 1989. Current protocols in molecular biology, p. 2.4.1-2.4.5. Wiley Intersciences, New York.

2. Beuscher, N., F. Mayer, and G. Gottschalk. 1974. Citrate lyase from Rhodopseudomonas gelatinosa: purification, electron microscopy and subunit structure. Arch. Microbiol. 100:307-328.

3. Biggin, M. D., T. J. Gibson, and G. F. Hing. 1983. Buffer gradient gels and $35 \mathrm{~S}$ label as an aid to rapid DNA sequence determination. Proc. Natl. Acad. Sci. USA 80:3963-3965.

4. Blotevogel, K., U. Fischer, M. Mocha, and S. Jannsen. 1985. Methanobacterium thermoalcaliphilum spec. nov., a new moderately alkaliphilic and thermophilic autotrophic methanogen. Arch. Microbiol. 142:211-217.

5. Collins, M. D., P. A. Lawson, A. Willems, J. J. Cordoba, J. FernandezGarayzabal, P. Garcia, J. Cai, H. Hippe, and J. A. E. Farrow. 1994. The phylogeny of the genus Clostridium: proposal of five new genera and eleven new species combinations. Int. J. Syst. Bacteriol. 44:812-826.

5a.Cook, G., et al. Unpublished data.

6. De Soete, G. 1983. A least squares algorithm for fitting additive trees to proximity data. Psychometrika 48:621-626.

7. Durre, P., W. Andersch, and J. R. Andreesen. 1981. Isolation and characterization of an adenine-utilizing, anaerobic sporeformer, Clostridium purinolyticum sp. nov. Int J. Syst. Bacteriol. 31:184-194.

8. Frasca, J. M., and V. R. Parks. 1965. A routine technique for doublestaining ultrathin sections using uranyl and lead salts. J. Cell Biol. 25: 157-161.

9. Freier, D., C. P. Mothershed, and J. Wiegel. 1988. Characterization of Clostridium thermocellum JW-20. Appl. Environ. Microbiol. 54:204-211.

10. Grant, W. D., W. E. Mwatha, and B. E. Jones. 1990. Alkaliphiles: ecology, diversity and applications. FEMS Microbiol. Rev. 75:255-270.

11. Horikoshi, K. 1990. Microorganisms in alkaline environments. Kodansha, Tokyo.

11a.International Committee on Systematic Bacteriology Subcommittee on Clostridia and Related Organisms. Unpublished data.

12. Jukes, T. H., and C. R. Cantor. 1969. Evolution of protein molecules, p. 21-132. In H. N. Munro (ed.), Mammalian protein metabolism. Academic Press, New York.

13. Kellenberger, E., A. Ryter, and J. Sechaud. 1958. Electron microscopy study of DNA-containing plasma. II. Vegetative and mature phage DNA as compared with normal bacterial nucleosides in different physiological states. J. Biophys. Biochem. Cytol. 4:671-678.

14. Kroll, R. G. 1990 . Alkaliphiles, p. 55-92. In C. Edwards (ed.), Microbiology of extreme environments. McGraw-Hill, New York.

15. Krulwich, T. A., and A. A. Guffanti. 1989. Alkalophilic bacteria. Annu. Rev. Microbiol. 43:435-463.

16. Lane, D. J., B. Pace, G. J. Olsen, and D. A. Stahl. 1985. Rapid determination of $16 \mathrm{~S}$ ribosomal RNA sequences for phylogenetic analyses. Proc. Natl. Acad. Sci. USA 82:6955-6959.
17. Lee, Y.-E., M. K. Jain, C. Lee, S. E. Lowe, and J. G. Zeikus. 1993. Taxonomic distinction of saccharolytic thermophilic anaerobes: description of Thermoanaerobacterium xylanolyticum gen. nov., sp. nov., and Thermoanaerobacterium saccharolyticum gen. nov., sp. nov.; reclassification of Thermoanaerobium brockii, Clostridium thermosulfurogenes, and Clostridium thermohydrosulfuricum E100-69 as Thermoanaerobacter brockii comb noy, Thermoanaerobacterium thermosulfurogenes comb. nov., and Thermoanaerobacter thermohydrosulfuricum comb. nov., respectively; and transfer of Clostridium thermohydrosulfuricum $39 \mathrm{E}$ to Thermoanaerobacter ethanolicus. Int. J. Syst. Bacteriol. 43:41-51.

18. Li, Y., M. Engle, N. Weiss, L. Mandelco, and J. Wiegel. 1994. Clostridium thermoalcaliphilum sp. nov., an anaerobic thermotolerant facultative alkaliphile. Int. J. Syst. Bacteriol. 43:111-118.

19. Li, Y., L. Mandelco, and J. Wiegel. 1993. Isolation and characterization of a moderately thermophilic alkaliphile, Clostridium paradoxum sp. nov. Int. J. Syst. Bacteriol. 43:450-460.

20. Lowe, S. E., M. K. Jain, and J. G. Zeikus. 1993. Biology, ecology, and biotechnological applications of anaerobic bacteria adapted to environmental stresses in temperature, $\mathrm{pH}$, salinity, and substrates. Microbiol. Rev. 57:451-509.

21. Maidak, B. L., N. Larson, M. J. McCaughey, R. Overbeek, G. J. Olsen, K. Fogel, J. Blandy, and C. R. Woese. 1994. The Ribosomal Database Project. Nucleic Acids Res. 22:3485-3487.

22. Marmur, J. 1961. A procedure for the isolation of deoxyribonucleic acid from microorganisms. J. Mol. Biol. 3:208-218.

23. Mathrani, I. M. D. R. Boone, R. A. Mah, G. E. Fox, and P. P. Lau. 1988 Methanohalophilus zhilinae sp. nov., an alkaliphilic, halophilic, methanotrophic methanogen. Int. J. Syst. Bacteriol. 38:139-142.

24. Mesbah, M., U. Premachandran, and W. B. Whitman. 1989. Precise measurement of the $\mathrm{G}+\mathrm{C}$ content of deoxyribonucleic acid by high-performance liquid chromatography. Int. J. Syst. Bacteriol. 39:159-167.

25. Niimur, Y., E. Koh, F. Yanagida, K.-I. Suzuki, K. Komagata, and M. Kozaki. 1990. Amphibacillus xylanus gen. nov., sp. nov., a facultatively anaerobic sporeforming xylan-digesting bacterium which lacks cytochrome, quinone, and catalase. Int. J. Syst. Bacteriol. 40:297-301.

26. Olsen, G. J., H. Matsuda, R. Hagstrom, and R. Overbeek. 1994. fastDNAml a tool for construction of phylogenetic trees of DNA sequences using maximum likelihood. CABIOS 10:41-48.

27. Olsen, G. J., R. Overbeek, N. Larson, T. L. Marsh, M. J. McCaughey, M. A. Maclukenas, W. M. Kaun, T. J. Macke, and C. R. Woese. 1992. The Ribosomal Database Project. Nucleic Acids Res. 20(Suppl.):2199-2200.

28. Sanger, F., S. Nicklen, and A. R. Coulson. 1977. DNA sequencing with chain-terminating inhibitors. Proc. Natl. Acad. Sci. USA 74:5463-5467.

29. Schleifer, K. H., and O. Kandler. 1972. Peptidoglycan types of bacterial cell walls and their taxonomic implications. Bacteriol. Rev. 36:407-477.

30. Sharp, R. J., and M. J. Munster. 1986. Biotechnological implications for microorganisms from extreme environments, p. 215-295. In R. A. Herbert and G. A. Codd (ed.), Microbes in extreme environments. Academic Press, London.

31. Shiba, H., H. Yamamoto, and K. Horikoshi. 1989. Isolation of strictly anaerobic halophiles from the aerobic surface sediments of hypersaline environments in California and Nevada. FEMS Microbiol. Lett. 57:191-196.

32. Spurr, A. R. 1969. A low-viscosity epoxy resin embedding medium for electron microscopy. J. Ultrastruct. Res. 26:31-43.

33. Stadtman, T. C., and H. A. Barker. 1951. Studies on the methane fermentation. X. A new formate-decomposing bacterium, Methanococcus vannielli. J. Bacteriol. 62:269-280.

34. Valentine, R. C., B. M. Shapiro, and E. R. Stadtman. 1968. Regulation of glutamine synthetase. XII. Electron microscopy of the enzyme from $E$. coli. Biochemistry 7:2143-2152.

35. Vedder, A. 1935. Bacillus alcalophilus n. sp.; benevens enkle ervaringen met sterk alcalische voedingsbodems. Antonie van Leeuwenhoek J. Microbiol. Serol. 1:141-147.

36. Viljoen, J. A., E. B. Fred, and W. H. Peterson. 1926. The fermentation of cellulose by thermophilic bacteria. J. Agric. Sci. 16:1-17.

37. Weisburg, W. G., J. G. Tully, D. L. Rose, J. P. Petzel, H. Oyaizu, D. Yang, L. Mandelco, J. Sechrest, T. G. Lawrence, J. van Etten, J. Maniloff, and C. R. Woese. 1989. A phylogenetic analysis of the mycoplasmas: basis for their classification. J. Bacteriol. 171:6455-6467. 
38. Whitman, W. B., S. Sohn, D. S. Caras, and U. Premachandran. 1986. Isolation and characterization of 22 mesophilic methanococci. Syst. Appl. Microbiol. 7:235-240.

39. Wiegel, J., L. G. Ljundahl, and J. R. Rawson. 1979. Isolation from soil and properties of the extreme thermophile Clostridium thermohydrosulfuricum. J. Bacteriol. 139:800-810.

40. Woese, C. R., R. Gutell, R. Gupta, and H. F. Noller. 1983. Detailed analysis of the higher-order structure of $16 \mathrm{~S}$-like ribosomal ribonucleic acids. Microbiol. Rev. 47:621-669.
41. Woese, C. R., M. Sogins, D. A. Stahl, B. J. Lewis, and L. Bonen. 1976. A comparison of the $16 \mathrm{~S}$ ribosomal RNAs from mesophilic and thermophilic bacilli. J. Mol. Evol. 7:197-213.

42. Workakit, S., D. R. Boone, R. A. Mah, M.-E. Abdel-Samie, and M. M. El-Halwagi. 1986. Methanobacterium alcaliphilum sp. nov., an $\mathrm{H}_{2}$-utilizing methanogen that grows at high pH values. Int. J. Syst. Bacteriol. 36:380-382.

43. Zeikus, J. G., and D. L. Henning. 1975. Methanobacterium arbophilicum sp. nov., an obligate anaerobe isolated from wetwood of living trees. Antonie van Leeuwenhoek J. Microbiol. Serol. 41:543-552. 